\title{
Clinical Reasoning: A 49-Year-Old Woman With Progressive Numbness and Gait Instability
}

Anza Zahid, MD, Shailee Shah, MD, Jennifer M. Martinez-Thompson, MD, Courtney A. Arment, MD, Yajue Huang, MD, Charles D. Sturgis, MD, and Divyanshu Dubey, MD

Neurology ${ }^{\circledR} 2021 ; 97: 342-347$. doi:10.1212/WNL.0000000000012135

\section{Section 1}

A 49-year-old woman with no relevant medical history presented to an external neurology clinic with progressive hand and foot paresthesia and gait instability for over 6 months. Initially, she reported tingling and shooting electrical-type sensations involving her feet. Within several weeks of the onset of paresthesia, she noted a burning pain sensation involving the left hand. Sensory symptoms continued to worsen and she felt pressure-like sensation around the neck and scalp region. This was shortly followed by right hand numbness and loss of dexterity. Over the next month, she developed progressive gait imbalance and transitioned to a cane for ambulation.

On examination, the patient had reduced sensation to pinprick, light touch, and temperature involving bilateral upper and lower extremities distally. She had asymmetrically reduced sensation to vibration and proprioception in her feet more prominently on the left. She also had pseudoathetosis and asymmetric sensory ataxia on finger-nose testing with her eyes closed without appendicular ataxia when testing finger-to-nose or heel-to-shin with open eyes. Romberg sign was positive. She had a wide-based gait and was unable to ambulate without support. Deep tendon reflexes in the bilateral lower extremities were absent. Strength and tone were normal in all extremities and cranial nerve examination was unremarkable.

\section{Questions for Consideration:}

1. What is the best localization of her deficit?

2. What is the differential diagnosis for a patient with progressive asymmetric sensory loss and ataxia?

\author{
Correspondence \\ Dr. Dubey \\ dubey.divyanshu@mayo.edu
}

\section{GO TO SECTION 2}




\section{Section 2}

The patient's sensory impairment with prominent sensory ataxia, absence of weakness, and depressed reflexes suggest a peripheral nerve localization, involving the large (proprioception and vibration) and small (pain and temperature) sensory fiber. The asymmetry and non-length-dependent upper and lower extremity involvement further suggests involvement of the dorsal root ganglia, a sensory ganglionopathy/neuronopathy. Considering the localization and subacute onset, the differential diagnosis includes vitamin $\mathrm{B}_{6}$ toxicity, drug toxicity with platinumbased chemotherapy, neurologic manifestations of systemic autoimmune diseases (Sjögren syndrome, mixed connective tissue disease, rheumatoid arthritis), paraneoplastic neurologic syndromes, infectious etiologies like HIV or varicella-zoster virus, and idiopathic sensory ganglionopathy. ${ }^{1,2}$

Pertinent laboratory testing to evaluate the etiology of sensory neuronopathy initially performed at an external neurology clinic included unremarkable vitamin $\mathrm{B}_{6}$, antinuclear antibody, anti-Ro/SSA and anti-La/SSB antibodies, and HIV serology. Electrodiagnostic testing demonstrated asymmetric, non-length-dependent low-amplitude sensory nerve action potentials supportive of a sensory ganglionopathy, contrary to symmetric and length-dependent sensory action potential amplitude changes observed in sensory axonal neuropathy. CSF evaluation showed protein $48 \mathrm{mg} / \mathrm{dL}$, total nucleated cells 1 cell $/ \mu \mathrm{L}$, glucose $57 \mathrm{mg} /$ $\mathrm{dL}$, normal immunoglobulin $\mathrm{G}$ ( $\mathrm{IgG}$ ) index, and absence of supernumerary CSF oligoclonal bands. MRI brain and cervical, thoracic, and lumbar spine with contrast were normal. A CT chest was performed to investigate for hilar adenopathy or occult malignancy and showed presence of enlarged mediastinal lymph nodes. An endobronchial ultrasound-guided fine-needle aspiration biopsy (FNAEBUS) was performed, revealing non-necrotizing granulomas (figure).

\section{Questions for Consideration:}

1. What is the most likely diagnosis?

2. Is the patient's neurologic presentation consistent with histopathologic findings?
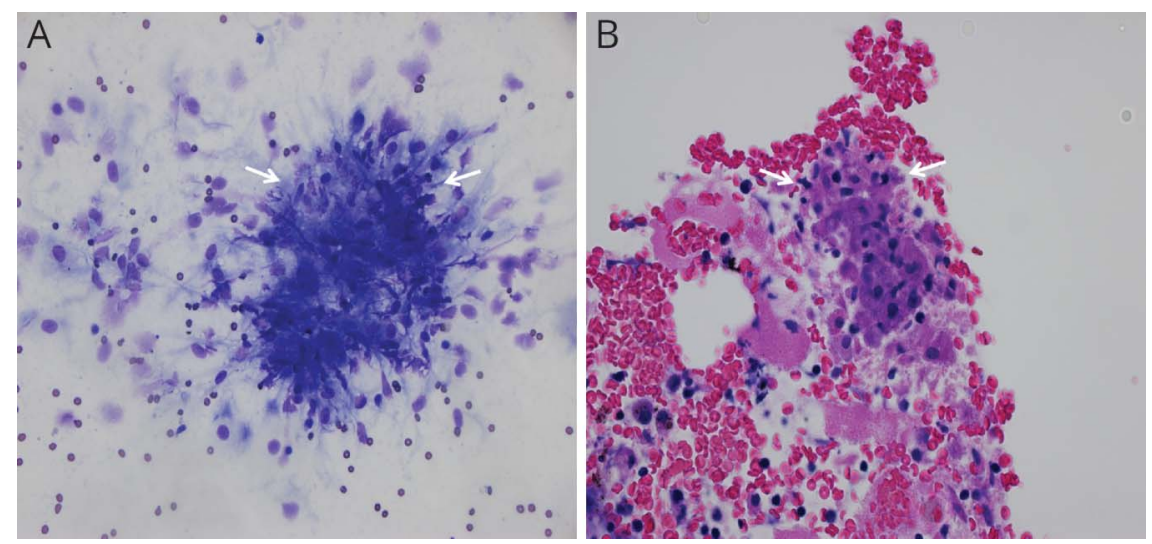

Non-necrotizing microgranuloma (arrow shows cohesive aggregate of spindled and epithelioid macrophages) detected on fine needle aspiration of mediastinal lymph node and direct smear: modified Giemsa (differential quick), 200× (A); hematoxylin \& eosin, 400× (B). 


\section{Section 3}

A sensory neuronopathy (ganglionopathy) secondary to neurosarcoidosis was presumed based on the patient's neurologic presentation and evidence of non-necrotizing granulomas on lymph node FNA-EBUS. She was started on oral prednisone (40 mg daily), which was tapered over 6 weeks without clinical improvement.

The patient subsequently had a focal onset seizure with secondary generalization. MRI brain showed T2 hyperintensity of the left medial temporal region suggestive of postictal change but routine EEG did not demonstrate epileptiform abnormalities or slowing. She was initially started on levetiracetam (500 mg twice daily) but due to adverse effects (increased agitation) was transitioned to lacosamide (200 mg twice daily).
A 4-day course of IV methylprednisolone $500 \mathrm{mg}$ daily was also initiated followed by oral prednisone $80 \mathrm{mg}$ daily. As the patient developed neuropsychiatric side effects on oral prednisone, it was tapered off. She was started on $7.5 \mathrm{mg}$ once weekly methotrexate and infliximab (5 mg/kg IV at 0, 2, and 6 weeks, followed by $5 \mathrm{mg} / \mathrm{kg}$ every 8 weeks thereafter).

Soon after, the patient developed bilateral sensorineural hearing loss, initially right-sided hearing impairment followed by involvement of the left side. She also developed facial numbness, diplopia, and dysarthria. Her gait instability continued to deteriorate, eventually requiring a wheelchair for safety.

\section{Question for Consideration:}

1. What additional investigations would you pursue at this stage?

GO TO SECTION 4 


\section{Section 4}

Due to new, progressive, multifocal neuroaxis deterioration with seizure and brainstem involvement suggestive of encephalitis, the patient was referred to a tertiary center for further management. Comprehensive history and laboratory investigations were performed including a paraneoplastic panel. The patient was positive for amphiphysin autoantibody in serum and CSF by tissue-based indirect immunofluorescence assay (serum titer 1:7680, CSF titer 1:256) and commercial EUROLINE immunodot (Euroimmun).
Amphiphysin autoantibodies are associated with breast cancer and lung cancer. ${ }^{2}$ Thus, to evaluate for occult malignancy, mammography and a PET-CT scan were performed. Mammography revealed scattered densities in the breast but no masses. On PET-CT, several enlarged hypermetabolic right axillary lymph nodes were detected. An ultrasound-guided core needle biopsy of a right axillary lymph node was performed with pathology confirmation of metastatic invasive ductal carcinoma.

\section{Questions for Consideration:}

1. What is the diagnosis?

2. What is the most appropriate treatment strategy?

GO TO SECTION 5 


\section{Section 5}

The patient was diagnosed with a paraneoplastic sensory neuronopathy and encephalitis consistent with the diagnosis of paraneoplastic encephalomyelitis, a multifocal neurologic disorder considered a classical paraneoplastic neurologic syndrome. Her paraneoplastic encephalomyelitis was due to amphiphysin autoantibodies, in association with metastatic invasive ductal breast carcinoma. She underwent 5 sessions of plasmapheresis and 5 days of 1 gram IV methylprednisolone, which were well tolerated. Infliximab and methotrexate were discontinued. She underwent surgical removal of the axillary lymph nodes, with 15 of 18 resected lymph nodes positive for metastatic invasive ductal carcinoma. Following initial immunotherapy and cancer resection, she reported significant improvement in neuropathic pain, numbness, hand dexterity, coordination, and gait. She transitioned from a wheelchair to a walker for ambulation. To prevent cancer recurrence, IV adriamycin and cyclophosphamide (4 cycles) followed by weekly paclitaxel has been planned.

\section{Discussion}

Amphiphysin autoantibodies were first identified in patients with paraneoplastic stiff-person syndrome. ${ }^{3}$ Since the initial description, the phenotypic associations have broadened to include peripheral neuropathy, particularly polyradiculoneuropathy or sensory neuronopathy. ${ }^{4}$ The majority of the amphiphysin neuropathy cases have been reported to have coexisting CNS involvements (57\%). ${ }^{4}$ Breast adenocarcinoma and small cell lung cancer are the most commonly reported malignancies among amphiphysin IgG-seropositive patients. ${ }^{2}$ Our amphiphysin IgG-seropositive patient shared many of the described associations including sensory neuronopathy at disease onset, progressive course with CNS involvement, and new diagnosis of breast adenocarcinoma supporting the final paraneoplastic diagnosis.

Granulomatous inflammation, or a sarcoidosis-like reaction, has been reported among various malignancies, including breast cancer. ${ }^{5}$ This is hypothesized to be due to the host's antitumor immune response, which may limit tumor growth or metastasis. ${ }^{6}$ Sarcoidosis-like reactions have also been demonstrated after administration of immune checkpoint inhibitors. ${ }^{7}$

Paraneoplastic autoimmunity is often associated with tumors that can incite a strong host immune response. ${ }^{8}$ An immune response directed at the tumor and neural antigens may result in more favorable oncologic responses in paraneoplastic neurologic syndromes. ${ }^{8}$ Regressed or "burned-out" germ cell tumors among patients with paraneoplastic rhombencephalitis may be another example of a strong host antitumor response. ${ }^{9}$ Immunogenic tumors like breast cancer may similarly develop sarcoidosis-like reactions ${ }^{5}$ and such findings among patients presenting subacute progressive neurologic syndrome should prompt evaluation for paraneoplastic disease.
This clinical vignette highlights that all patients presenting with subacute, non-length-dependent, and asymmetric sensory complaints should be carefully evaluated by comprehensive electrodiagnostic studies. Among patients presenting with sensory neuronopathy, paraneoplastic neurologic syndrome should be a part of differential diagnosis and onconeural antibody evaluation should be considered. ${ }^{4}$ Common autoantibodies associated with sensory neuronopathy presentation include anti-neuronal nuclear antibody type 1 (ANNA1 or anti-Hu) and collapsin response-mediator protein 5 (CRMP5 or anti-CV2), and less often amphiphysin or Purkinje cell cytoplasmic antibody type 2 (PCA2). ${ }^{2,10,11}$ Progressive neurologic deterioration after administration of tumor necrosis factor- $\alpha$ inhibitors in patients with presumed neurosarcoidosis should lead to consideration of alternative autoimmune etiologies. ${ }^{12}$ Finally, sensory neuronopathy with multifocal neurologic axis involvement is uncommon for neurosarcoidosis. ${ }^{13}$ Granulomatous inflammation can be seen in paraneoplastic diseases due to potent antitumor immune responses. For such atypical presentations, onconeural antibody testing should be considered.

\section{Study Funding}

The authors report no targeted funding.

\section{Disclosure}

A. Zahid, S. Shah, J.M. Martinez-Thompson, C.A. Arment, Y. Huang, and C.D. Sturgis report no disclosures relevant to the manuscript. D. Dubey reports research support from Center of Multiple Sclerosis and Autoimmune Neurology, Center for Clinical and Translational Science, and has consulted for UCB and Astellas pharmaceuticals. All compensation for consulting activities is paid directly to Mayo Clinic. Dr. Dubey has a patent pending for KLHL11-IgG and LUZP4 IgG as markers of neurologic autoimmunity. Go to Neurology.org/ $\mathrm{N}$ for full disclosures.

\begin{tabular}{|c|c|c|}
\hline Name & Location & Contribution \\
\hline Anza Zahid, MD & $\begin{array}{l}\text { Mayo Clinic, } \\
\text { Rochester, } \\
\text { MN }\end{array}$ & $\begin{array}{l}\text { Acquired the data, analyzed the data, } \\
\text { interpreted the data, drafted the } \\
\text { manuscript }\end{array}$ \\
\hline Shailee Shah, MD & $\begin{array}{l}\text { Mayo Clinic, } \\
\text { Rochester, } \\
\text { MN }\end{array}$ & $\begin{array}{l}\text { Acquired the data, interpreted the } \\
\text { data, revised the manuscript for } \\
\text { intellectual content }\end{array}$ \\
\hline $\begin{array}{l}\text { Jennifer M. } \\
\text { Martinez- } \\
\text { Thompson, MD }\end{array}$ & $\begin{array}{l}\text { Mayo Clinic, } \\
\text { Rochester, } \\
\text { MN }\end{array}$ & $\begin{array}{l}\text { Interpreted the data, revised the } \\
\text { manuscript for intellectual content }\end{array}$ \\
\hline $\begin{array}{l}\text { Courtney A. } \\
\text { Arment, MD }\end{array}$ & $\begin{array}{l}\text { Mayo Clinic, } \\
\text { Rochester, } \\
\text { MN }\end{array}$ & $\begin{array}{l}\text { Interpreted the data, revised the } \\
\text { manuscript for intellectual content }\end{array}$ \\
\hline Yajue Huang, MD & $\begin{array}{l}\text { Mayo Clinic, } \\
\text { Rochester, } \\
\text { MN }\end{array}$ & $\begin{array}{l}\text { Interpreted the data, revised the } \\
\text { manuscript for intellectual content }\end{array}$ \\
\hline
\end{tabular}


Appendix (continued)

\begin{tabular}{lll}
\hline Name & Location & Contribution \\
\hline $\begin{array}{l}\text { Charles D. Sturgis, } \\
\text { MD }\end{array}$ & $\begin{array}{l}\text { Mayo Clinic, } \\
\text { Rochester, } \\
\text { MN }\end{array}$ & $\begin{array}{l}\text { Interpreted the data, revised the } \\
\text { manuscript for intellectual content }\end{array}$ \\
\hline $\begin{array}{l}\text { Divyanshu Dubey, } \\
\text { MD }\end{array}$ & $\begin{array}{l}\text { Mayo Clinic, } \\
\text { Rochester, } \\
\text { MN }\end{array}$ & $\begin{array}{l}\text { Designed and conceptualized study, } \\
\text { analyzed the data, drafted the } \\
\text { manuscript, revised the manuscript } \\
\text { for intellectual content, study } \\
\text { supervision }\end{array}$ \\
\hline
\end{tabular}

\section{References}

1. Amato AA, Ropper AH. Sensory ganglionopathy. N Engl J Med. 2020;383:1657-1662

2. Mathis S, Duval F, Soulages A, Solé G, Le Masson G. The ataxic neuropathies. J Neurol. Epub 2020 Jun 15

3. De Camilli P, Thomas A, Cofiell R, et al. The synaptic vesicle-associated protein amphiphysin is the $128-\mathrm{kD}$ autoantigen of stiff-man syndrome with breast cancer. J Exp Med. 1993;178(6):2219-2223.
4. Dubey D, Jitprapaikulsan J, Bi H, et al. Amphiphysin-IgG autoimmune neuropathy: a recognizable clinicopathologic syndrome. Neurology. 2019;93(20):e1873-e1880.

5. Martella S, Lohsiriwat V, Barbalho DM, et al. Sarcoid-like reaction in breast cancer: a long-term follow-up series of eight patients. Surg Today. 2012;42(3):259-263.

6. Steinfort DP, Irving LB. Sarcoidal reactions in regional lymph nodes of patients with non-small cell lung cancer: incidence and implications for minimally invasive staging with endobronchial ultrasound. Lung Cancer. 2009;66(3):305-308.

7. Gkiozos I, Kopitopoulou A, Kalkanis A, Vamvakaris IN, Judson MA, Syrigos KN. Sarcoidosis-like reactions induced by checkpoint inhibitors. J Thorac Oncol. 2018; 13(8):1076-1082.

8. Darnell RB. Onconeural antigens and the paraneoplastic neurologic disorders: at the intersection of cancer, immunity, and the brain. Proc Natl Acad Sci USA. 1996;93(10):4529-4536.

9. Dubey D, Wilson MR, Clarkson B, et al. Expanded clinical phenotype, oncological associations, and immunopathologic insights of paraneoplastic kelch-like protein-11 encephalitis. JAMA Neurol. 2020;77(11):1-10.

10. Lucchinetti CF, Kimmel DW, Lennon VA. Paraneoplastic and oncologic profiles of patients seropositive for type 1 antineuronal nuclear autoantibodies. Neurology. 1998; 50(3):652-657.

11. Jitprapaikulsan J, Klein CJ, Pittock SJ, et al. Phenotypic presentations of paraneoplastic neuropathies associated with MAP1B-IgG. J Neurol Neurosurg Psychiatry. 2020;91(3):328-330.

12. Kunchok A, Aksamit AJ Jr, Davis JM III, et al. Association between tumor necrosis factor inhibitor exposure and inflammatory central nervous system events. JAMA Neurol .2020;77(8):937-946.

13. Zuniga G, Ropper AH, Frank J. Sarcoid peripheral neuropathy. Neurology. 1991; $41(10): 1558$

\section{Get NeuroReady!}

Preparing for the neurology boards? Up for recertification? Looking for a solid foundational knowledge in neurology? Get ready with the AAN's convenient online courses-NeuroReady: Board Prep Edition or NeuroReady: Continuing Certification Edition, and the new NeuroReady: Advanced Practice Provider Edition. Includes 12 months of access. Get ready to review, self-assess, and succeed at AAN.com/NeuroReady.

\section{Sign Up for the AAN's Axon Registry}

The AAN encourages its US members to show their interest in participating in the Axon Registry by signing up today.

Use the Axon Registry to:

- Simplify reporting requirements under MACRA's Quality Payment Program and avoid penalties while reducing your administrative burden

- Meet your MOC Part IV requirements and waive up to eight credits of Part II Self-Assessment

- Choose from 22 AAN neurology-specific quality measures that fit your practice

- Use data to understand your practice and identify where improvements can be made to patient care

- Manage your patients at a population level; look at a specific group of patients based on conditions, risk factors, demographics or outcome

- Demonstrate your value to payers when negotiating reimbursement

- Enjoy multi-year, fee-free access when you sign the agreements and integrate your EHR with the registry

Learn more at AAN.com/view/Axon and send your questions to registry@aan.com. 


\section{Neurology}

\section{Clinical Reasoning: A 49-Year-Old Woman With Progressive Numbness and Gait Instability}

Anza Zahid, Shailee Shah, Jennifer M. Martinez-Thompson, et al.

Neurology 2021;97;342-347 Published Online before print April 30, 2021

DOI 10.1212/WNL.0000000000012135

\section{This information is current as of April 30, 2021}

\section{Updated Information \&} Services

References

Subspecialty Collections

Permissions \& Licensing

Reprints including high resolution figures, can be found at: http://n.neurology.org/content/97/7/342.full

This article cites 12 articles, 6 of which you can access for free at: http://n.neurology.org/content/97/7/342.full\#ref-list-1

This article, along with others on similar topics, appears in the following collection(s):

Autoimmune diseases

http://n.neurology.org/cgi/collection/autoimmune_diseases Paraneoplastic syndrome

http://n.neurology.org/cgi/collection/paraneoplastic_syndrome Peripheral neuropathy

http://n.neurology.org/cgi/collection/peripheral_neuropathy

Information about reproducing this article in parts (figures,tables) or in its entirety can be found online at:

http://www.neurology.org/about/about_the_journal\#permissions

Information about ordering reprints can be found online:

http://n.neurology.org/subscribers/advertise

Neurology ${ }^{\circledR}$ is the official journal of the American Academy of Neurology. Published continuously since 1951, it is now a weekly with 48 issues per year. Copyright () 2021 American Academy of Neurology. All rights reserved. Print ISSN: 0028-3878. Online ISSN: 1526-632X.

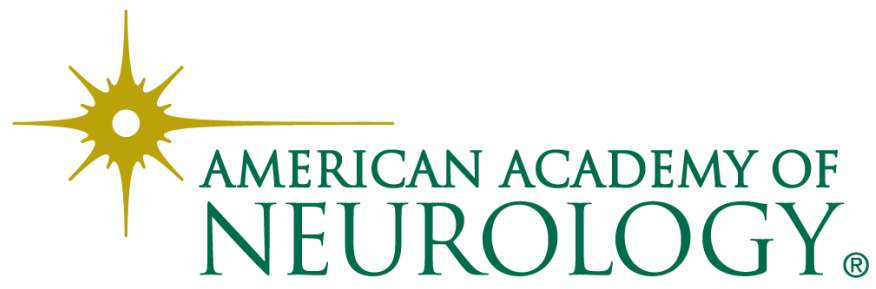

